\title{
Science and Non-Science Teachers' Views about Astronomy Diagrams in Middle School Science Textbooks
}

\author{
Hasan Özgür KAPICI*, Ünsal UMDU TOPSAKAL**
}

* Rsc. Asst., Y1ldız Technical University, Faculty of Education, Department of Primary Science Education, 34220 Istanbul, Turkey E- mail: ozgurhsn@gmail.com

** Assoc. Prof. Dr., Y1ld1z Technical University, Faculty of Education, Department of Primary Science Education, 34220 Istanbul, Turkey E-mail: topsakal@yildiz.edu.tr

Copyright (C) 2015 Hasan Özgür KAPICI and Ünsal UMDU TOPSAKAL. This is an open access article distributed under the Eurasian Academy of Sciences License, which permits unrestricted use, distribution, and reproduction in any medium, provided the original work is properly cited.

\begin{abstract}
In the present study, we have explored an aspect of teachers' perceptions of astronomy diagrams. The research was done in Turkey. The data were gathered from 40 teachers from primary and secondary schools. Some of the participants (20 teachers) are science specialist teachers and the others (20 teachers) are non-science specialist teachers. The study is based on a qualitative approach. Firstly, astronomy diagrams from the middle school science textbooks were chosen by the researchers. Then the selected diagrams were shown to the teachers and they were asked what they see when they look at these selected astronomy diagrams. The data was treated by qualitative data analysis (open coding). It is indispensible fact that science specialist teachers and non-science specialist teachers have different knowledge about astronomy topics. However, while looking at the images, there are no much different responses (arrow, colour, text etc.) between these two groups of teachers. We conclude that it may be helpful to train teachers in the processes of constructing and reading diagrams.
\end{abstract}

Keywords: Diagram, astronomy teaching, astronomy learning

\section{Fen Bilgisi ve Fen Bilgisi Alan Dışı Öğretmenlerin Ortaokul Fen Bilgisi Ders Kitaplarında Yer Alan Astronomi Görselleri İle İlgili Görüşleri \\ ÖZET}

$\mathrm{Bu}$ çalışmada öğretmenlerin astronomi görselleri hakkındaki görüş ve algıları incelenmiştir. Çalışma Türkiye'de gerçekleştirilmiştir. Veriler 40 ilkokul ve ortaokul öğretmeninden elde edilmiştir. 20 öğretmen Fen Bilgisi alanında , 20 öğretmen ise diğer braşlarda görev yapmaktadır. Araştırma bir nitel çalışma olarak dizayn edilmiştir. Öncelikle ortaokul fen bilgisi ders kitaplarında yer alan astronomi görselleri araştırmacılar tarafından seçilmiştir. Daha sonra seçilen görseller öğretmenlere gösterilerek, görsellerde dikkatlerini nelerin çektiği sorulmuştur.Veriler açık kodlama ile analiz edilmiştir. Çalışma sonunda beklenen şekilde fen bilgisi öğretmenleri ile fen bilgisi alan dışı öğretmenlerin görseller hakkında farklı düzeyde bilgi sahibi oldukları ancak her iki grubunda görsellerde dikkatlerini çeken unsurların ( ok, renk, metin yazısı..vb.) çok farklı olmadığı görülmüştür. Çalışma sonunda öğretmenlerin 
diagramları oluşturma ve okuma konusunda eğitim almaları gerektiği sonucuna varilabilmektedir.

\section{Introduction}

Astronomy is one of the popular socio-scientific issues that have been appeared by mass media (Pena \& Quilez, 2001). This makes attractive the topic for students in order to study about it. On the other hand, most cultures have a variety of stories to explain the events we see in the sky everyday but the paradox is that some of the most readily experienced phenomena such as day and night, the phases of the Moon, and the seasons can only be understood using complex and non-intuitive explanations (Lelliott \& Rollnick, 2010, p.1772). In addition, astronomy education and research related to astronomy education has been ignored for many years (Bektaşl1, 2014). Because of these, students may have misconceptions about fundamental astronomy concepts before and even after the instruction.

Astronomy is a subject of study throughout the different levels of primary and secondary education (Pena \& Quilez, 2001, p.1125). In new science education curriculum (MEB, 2013) of middle school (grade 5, 6, 7, 8) in Turkey, approximately 13\% of science education curriculum devoted to astronomy related topics (Bektaşl1, 2014).

Astronomy is not the unique topic that involves a lot of concepts which cannot be observed by a naked eye. Therefore, visualization may have a vital role for students to deal with such intangible concepts. In addition, textbooks are the most graphically populated print materials used for the communication and sharing of scientific ideas (Lee, 2010). If used well, they can be an effective tool to enhance teaching and learning (Nyachwaya \& Wood, 2014). There is a great abundance of photographs, drawings, diagrams and graphics about astronomy in textbooks which make the topic more attractive (Pena \& Quilez, 2001, p.1126).

In the literature there are many studies which investigate students', pre-service and in-service teachers' knowledge or mental models about basic astronomy concepts (Bektaşl1, 2014; Deming, 2001; Emrahoğlu \& Öztürk, 2009; Hudgins, Prather, Grayson \& Smits, 2006; Kalkan \& Kiroglu, 2007; Şahin, Bülbül \& Durukan, 2013). All these studies conclude that most of the individuals are lack of knowledge and have wrong mental models about the astronomy concepts. Bektaşlı (2014) advocates that in the case of astronomy education, teachers may transfer misconceptions to their students if they do not have sufficient knowledge of astronomy. For students to learn and understand the concepts about the topics, it is fundamentally important that these students' teachers have a strong understanding of astronomy concepts and how best to present these concepts to their students in an ageappropriate manner (Brunsell \& Marcks, 2005). Although it is indispensible fact that teachers have vital roles through learning process, there are limited studies which investigate in-service teachers' astronomy knowledge (Bektaşl1, 2014).

In the present study, the attention of science and nonscience specialist teachers to some features of astronomy diagrams are explored. 


\section{Method}

\section{Design of the research}

The study is based on a qualitative approach.

\section{Sampling}

The research was done in Turkey. The data were gathered from 40 teachers from primary and secondary schools. Some of the participants (20 teachers) are science specialist teachers and the others (20 teachers) are non-science specialist teachers. The professional fields of teachers are indicated in Figure 1.

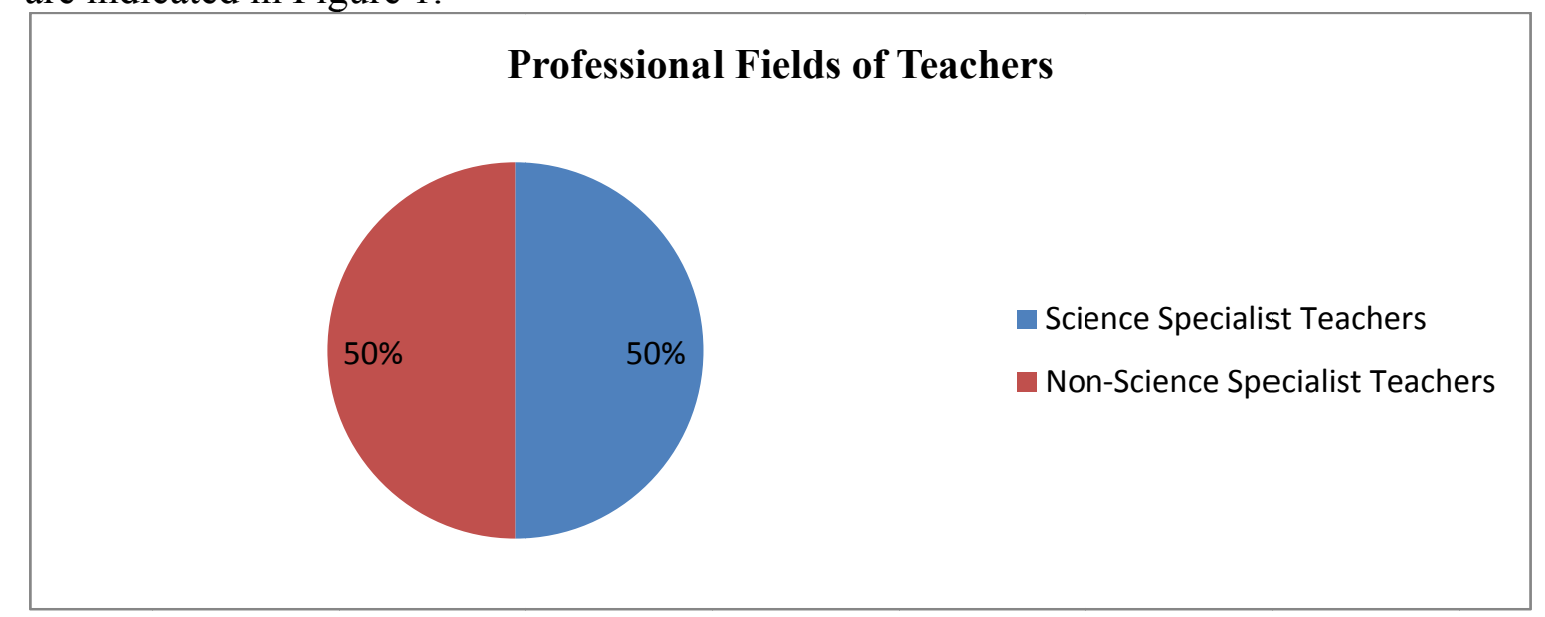

Figure 1: Professional Fields of Teachers

\section{Instrumentation and analysis}

First of all, astronomy diagrams from the middle school science textbooks were chosen by the researchers. When choosing diagrams, researchers selected the solar system (3), eclipse of the sun (3) and eclipse of the moon (3) diagrams. The images in Appendix 1 (Diagram 1, Diagram 2, Diagram 3) are about the solar system, in Appendix 2 (Diagram 4, Diagram 5, Diagram 6) are about eclipse of the moon and lastly, in Appendix 3 (Diagram 7, Diagram 8, Diagram 9) are about eclipse of the sun. In second step, the selected diagrams were shown to the teachers. In this step, the participants were informed that the researchers investigates how people read diagrams and they were asked what they see when they look at these selected astronomy diagrams. The teachers wrote their ideas about each diagram.

The main data analysis in the study is based on Grounded Theory which is a kind of qualitative data analysis. Allan (2003) explains the theory as rather than beginning with a hypothesis, the first step in the theory is gathering data through variety of methods and then from collected data, the key points are marked with a series of codes. For the next step, the codes are grouped into similar concepts and in the last step; categories are formed from these concepts.

\section{Results}

In this part, the results are given with respect to teachers' specializations. Firstly, science specialist teachers' results were given and then non-science teachers' results were shown. 


\section{Science Specialist Teachers' Views about the Astronomy Diagrams}

The analysis of science teachers' comments about the astronomy diagrams were classified into six different categories. These are exactly correct explanation, short/lack of explanation, wrong explanation, uninterested explanation, trying to find something wrong on image and emphasizing the properties of image. The number of teachers is placed into the Table 1 with respect to their comments. In addition, $*, * *$ or $* * *$ indicates that how many teachers have common views about the image.

\begin{tabular}{|c|c|c|c|c|c|c|c|c|c|}
\hline & $\begin{array}{l}\text { Image } \\
1\end{array}$ & $\begin{array}{l}\text { Image } \\
2\end{array}$ & $\begin{array}{l}\text { Image } \\
\mathbf{3}\end{array}$ & $\begin{array}{l}\text { Image } \\
4\end{array}$ & $\begin{array}{l}\text { Image } \\
5\end{array}$ & $\begin{array}{l}\text { Image } \\
6\end{array}$ & $\begin{array}{l}\text { Image } \\
7\end{array}$ & $\begin{array}{l}\text { Image } \\
8\end{array}$ & $\begin{array}{l}\text { Image } \\
9\end{array}$ \\
\hline $\begin{array}{l}\text { Exactly } \\
\text { correct } \\
\text { explanation }\end{array}$ & 9 & 5 & $5+1^{*}$ & $11+2^{*}$ & $8+3^{*}$ & $7+2 *$ & $9+2 *$ & $6+2 *$ & $8+1^{*}$ \\
\hline $\begin{array}{l}\text { Short/Lack } \\
\text { of correct } \\
\text { explanation }\end{array}$ & 3 & $8+1 *$ & 9 & 4 & 4 & 5 & 5 & 6 & 5 \\
\hline $\begin{array}{l}\text { Wrong } \\
\text { explanation }\end{array}$ & 8 & 5 & $2+1 * *$ & $2+1 * *$ & 2 & 5 & 1 & 4 & 2 \\
\hline $\begin{array}{l}\text { Uninterested } \\
\text { explanation }\end{array}$ & & 1 & $1+1 * * *$ & & $2+1 * *$ & $1 * *$ & $2+1 * *$ & $1+1^{* *}$ & $1+2 * *$ \\
\hline $\begin{array}{l}\text { Trying to } \\
\text { find } \\
\text { something } \\
\text { wrong on an } \\
\text { image }\end{array}$ & & & & $1 * *$ & & $1 * *$ & & & \\
\hline $\begin{array}{l}\text { Emphasizing } \\
\text { the } \\
\text { properties of } \\
\text { image }\end{array}$ & & $1^{*}$ & $\begin{array}{l}1^{*+1} 1^{* *} \\
+1^{* * *}\end{array}$ & $2 *$ & $3 *+1 * *$ & $2 *$ & $2 *+1 * *$ & $2 *+1 * *$ & $1 *+2 * *$ \\
\hline
\end{tabular}

Table 1: Science teachers' distributions into categories with respect to their comments

It is shown on the Table 1 that totally 13 teachers have exactly correct explanations about image 4, which the highest number of teachers for the exactly correct explanation category. On the other hand, whereas just five teachers commented the image 2 in a correct way, nine teachers explained it shortly or partially. Besides for the image 3, nine teachers' comments were not exact, too. Furthermore eight teachers have wrong explanations about image 1 which is utmost number of teachers for the wrong explanation category. For the uninterested category, three different teachers interpreted the image 5, 7 and 9. Only one teacher for image 4 and another one for image 6 tried to find something wrong on the images and criticized them. Lastly, four teachers emphasized the properties of image 5, which is the ultimate level, instead of its meaning.

\section{Non-Science Specialist Teachers' Views about the Astronomy Diagrams}

The analysis of non-science teachers' comments about the astronomy diagrams were also classified into six different categories same as science specialist ones. The number of teachers is placed into the Table 2 with respect to their comments. In addition, **** or *** also indicates that how many teachers have common views about the image. 


\begin{tabular}{|l|l|l|l|l|l|l|l|l|l|}
\hline & $\begin{array}{l}\text { Image } \\
\mathbf{1}\end{array}$ & $\begin{array}{l}\text { Image } \\
\mathbf{2}\end{array}$ & $\begin{array}{l}\text { Image } \\
\mathbf{3}\end{array}$ & $\begin{array}{l}\text { Image } \\
\mathbf{4}\end{array}$ & $\begin{array}{l}\text { Image } \\
\mathbf{5}\end{array}$ & $\begin{array}{l}\text { Image } \\
\mathbf{6}\end{array}$ & $\begin{array}{l}\text { Image } \\
\mathbf{7}\end{array}$ & $\begin{array}{l}\text { Image } \\
\mathbf{8}\end{array}$ & $\begin{array}{l}\text { Image } \\
\mathbf{9}\end{array}$ \\
\hline $\begin{array}{l}\text { Exactly } \\
\text { correct } \\
\text { explanation }\end{array}$ & $6+2^{*}$ & $6+1^{*}$ & $7+1^{*}$ & $7+1^{*}$ & $6+2^{*}$ & $6+1^{*}$ & 10 & 8 & 6 \\
\hline $\begin{array}{l}\text { Short/Lack } \\
\text { of correct } \\
\text { explanation }\end{array}$ & 5 & 9 & $\begin{array}{l}5+1^{* *+} \\
\mathbf{F}^{* *}\end{array}$ & $8+1^{* *}$ & 8 & 5 & 6 & 6 & 7 \\
\hline $\begin{array}{l}\text { Wrong } \\
\text { explanation }\end{array}$ & 5 & 1 & $3+1^{* *}$ & $2+1^{* *}$ & $3+1^{*}$ & $3+1^{*}$ & 2 & 3 & 3 \\
\hline $\begin{array}{l}\text { Uninterested } \\
\text { explanation }\end{array}$ & $\begin{array}{l}1+1^{*+} \\
1^{* *}\end{array}$ & 2 & 2 & 1 & 1 & 3 & 1 & $1^{*}$ & 2 \\
\hline $\begin{array}{l}\text { Trying to } \\
\text { find } \\
\text { something } \\
\text { wrong on an } \\
\text { image }\end{array}$ & $1^{*}$ & 1 & $1+1^{*}$ & $1 * * *$ \\
\hline $\begin{array}{l}\text { Emphasizing } \\
\text { the } \\
\text { properties of } \\
\text { image }\end{array}$ & $1^{* *}$ & $1^{*}$ & $1+1^{*+}$ & & & 1 & 1 & 1 & $1^{*}$ \\
\hline
\end{tabular}

Table 2: Non-science teachers' distributions into categories with respect to their comments

For the exactly correctly explanation category, 10 teachers for the image 7 were placed. This means that half of teachers have true interpretations about the image 7. In spite of that five teachers have wrong explanations for the image 1. Image 3,5 and 6 are other three images that four teachers have incorrect comments. Nine teachers for image 2 and image 4 have lack of explanations. They just interpreted the part of image(s). In addition, image 5, 9 and 3 are other images that have short explanations. One teacher almost for each image tried to find something wrong on image(s). Three teachers for image 1 and 6 have disinterested comments. Terminally, for image 3 , three teachers emphasized the properties of image.

The results show that image 1 is the most trouble one for two groups of teachers. Although the image is about the rotation of the Earth around the sun and the rotation of the moon around both the Earth and the sun, many teachers interpreted it as related with seasons or lunar eclipse. Image 6 is another difficult image for both groups of teachers. Whereas the image explains the lunar eclipse, some teachers associated it with penumbra. Moreover many teachers have short explanations about image 2 that is about planets' orbits, properties and configuration. This result may show that teachers have limited surface knowledge about planets and their locations on space. Image 3 is also about planetary system and again many teachers have lack of explanations. Furthermore teachers have disinterested interpretations for image 9 at the highest level that is about solar eclipse. In addition, some teachers emphasized the properties of image 3 frequently. They usually criticized the size of planets, the distance among themselves and their locations. Non-science specialized teachers tried to find something wrong on images more than science specialized ones.

\section{Discussion and Conclusion}

Diagrams are complex artifacts embedding conventions and seemingly simple elements such as lines, curves, color (sometimes) and object with boundaries (Topsakal \& Oversby, 2013). 
It is indispensible fact that science specialist teachers and non-science specialist teachers have different knowledge about astronomy topics. However, while looking at the images, there are no much different responses between these two groups of teachers. We conclude that it may be helpful to train teachers in the processes of constructing and reading diagrams.

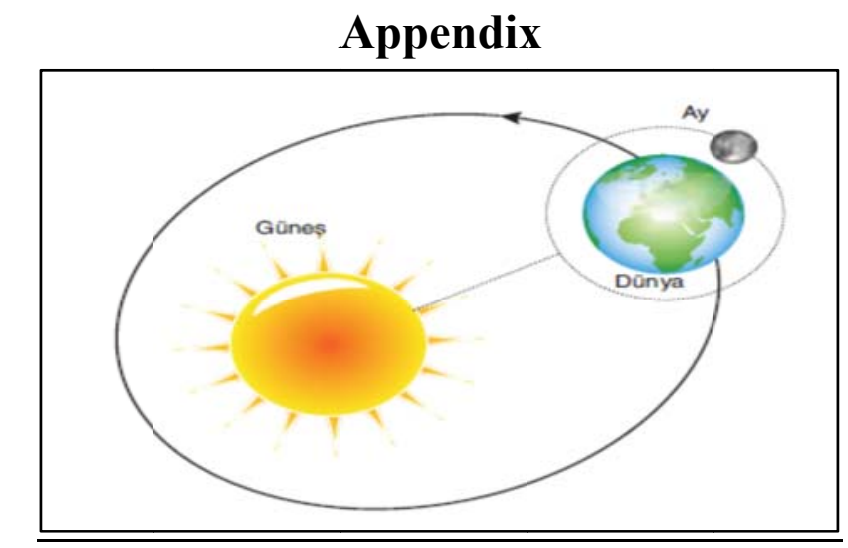

Image No 1: Ayan Taşdemir, Y. (2013). 7.sınıf Fen ve teknoloji ders kitabı. Güneşs sistemi ve ötesi: uzay bilmecesi (ss. 379-401). Ankara: Palme Yayınc1lık.

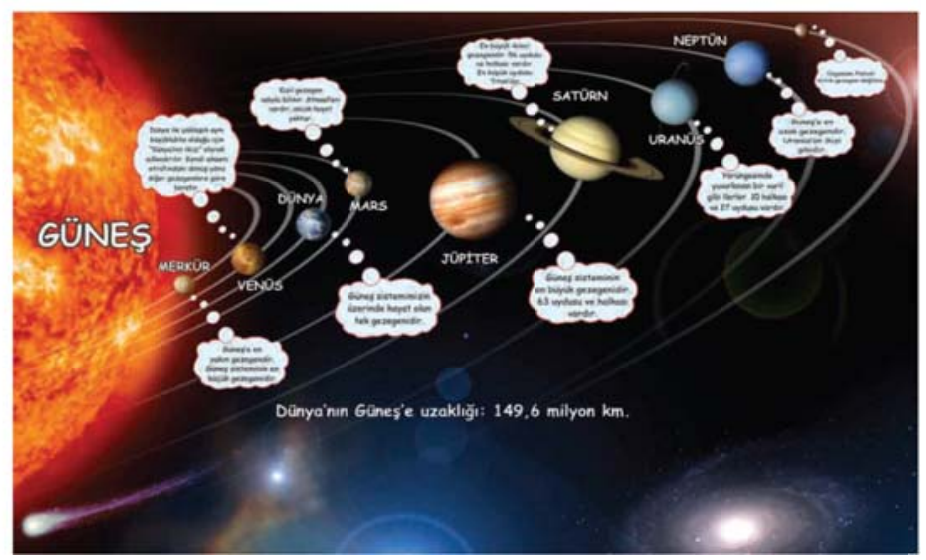

Image No 2: Ayan Taşdemir, Y. (2013). 7.sınıf Fen ve teknoloji ders kitabı. Güneş sistemi ve ötesi: uzay bilmecesi (ss. 379-401). Ankara: Palme Yayıncılık.

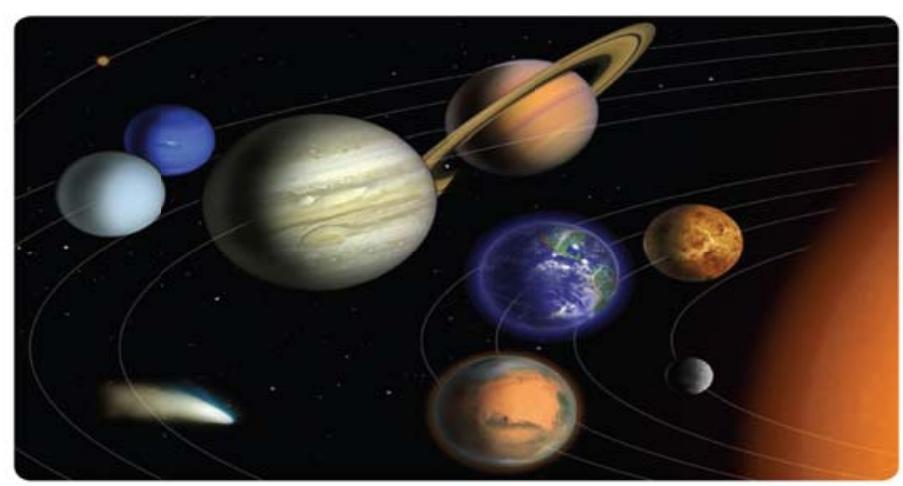


Image No 3: Boyraz Topaloğlu, Ş. (2012). 7.sınıf Fen ve teknoloji ders kitabı. Güneşsistemi ve ötesi: uzay bilmecesi (ss. 230-253). Ankara: Ekoyay Yayıncılık.

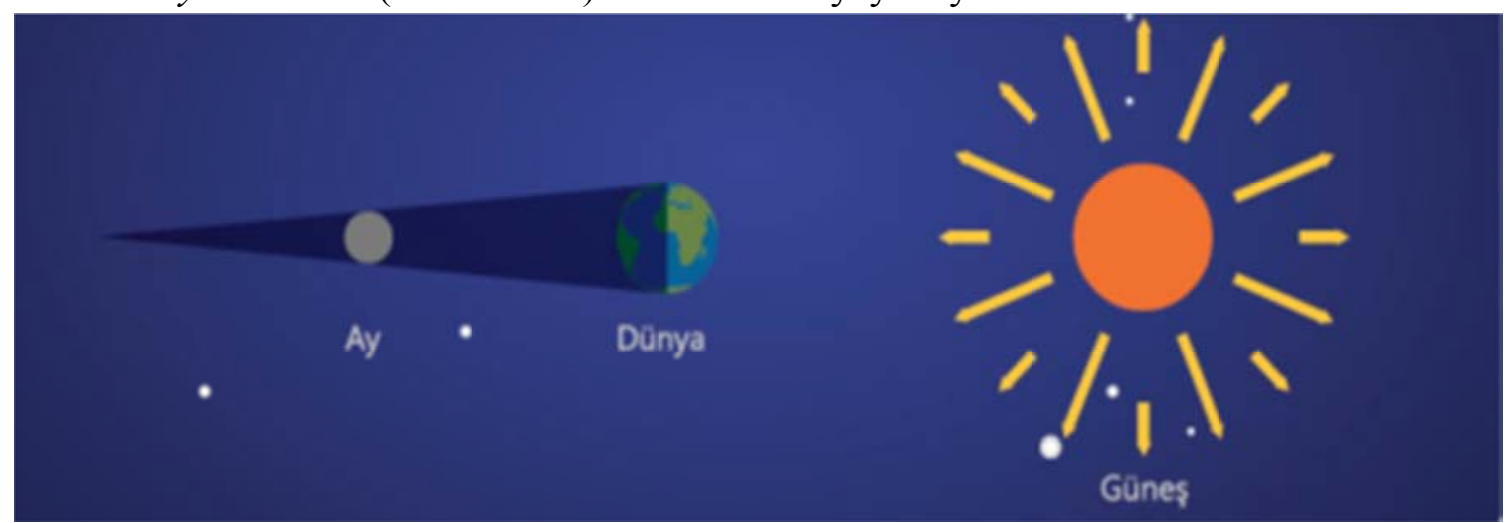

Image No 4: Gündüz, G. (2013). Ortaokul 5.sınıf fen bilimleri ders kitabı. Işığın ve sesin yayılması (ss. 96-118). Ankara: Evren Yayıncılık.

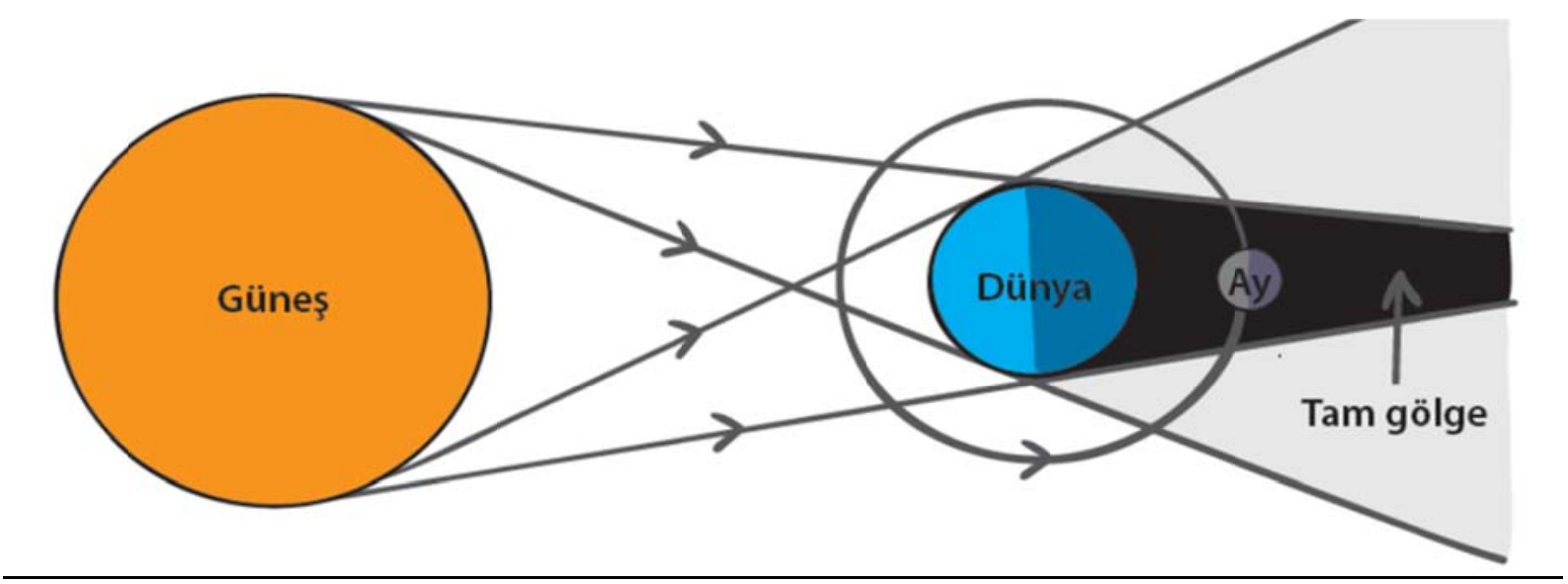

Image No 5: Komisyon (2014). Ortaokul 5.sınıf fen bilimleri ders kitabı. Işı̆̆ın ve sesin yayılması (ss. 161-216). Ankara: MEB Yayınları.

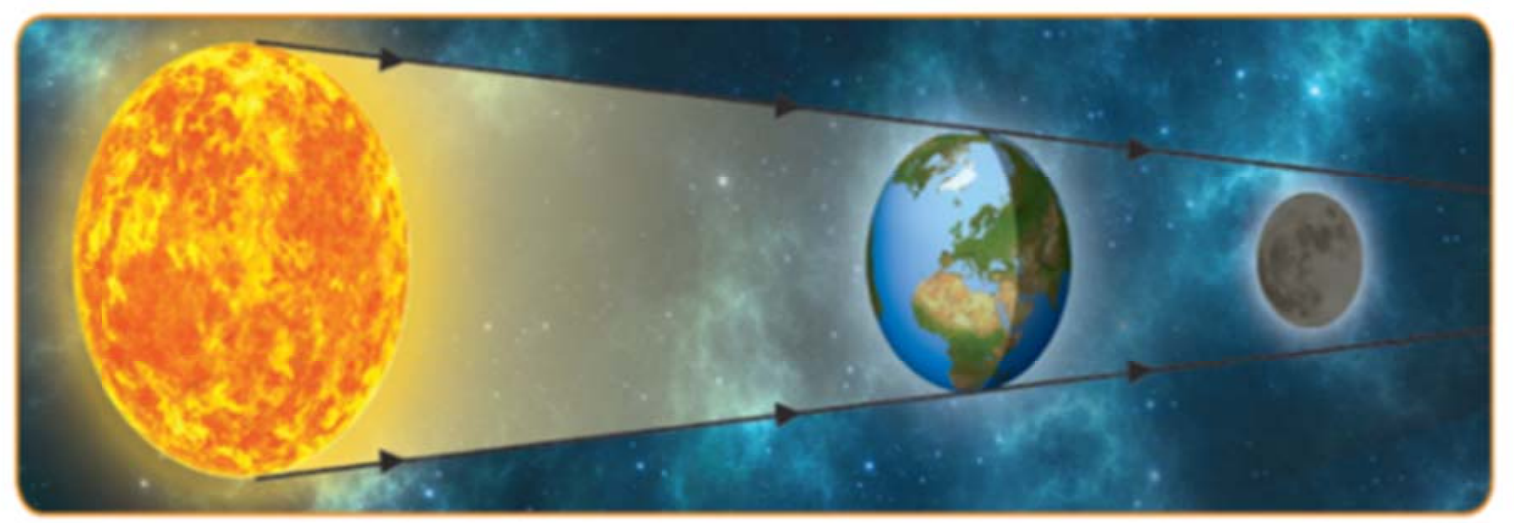

Image No 6: Bayram, G. \& Kibar, F. S. (2014). Ortaokul 5.sınıf fen bilimleri ders kitabı. Işığın ve sesin yayılması (ss. 103-120). Ankara: Sevgi Yayınları 


\begin{tabular}{|l|l|l|}
\hline 8 & & $\begin{array}{l}\text { Science and Non-Science Teachers' Views about Astronomy Diagrams in Middle School Science } \\
\text { Textbooks }\end{array}$ \\
\hline
\end{tabular}

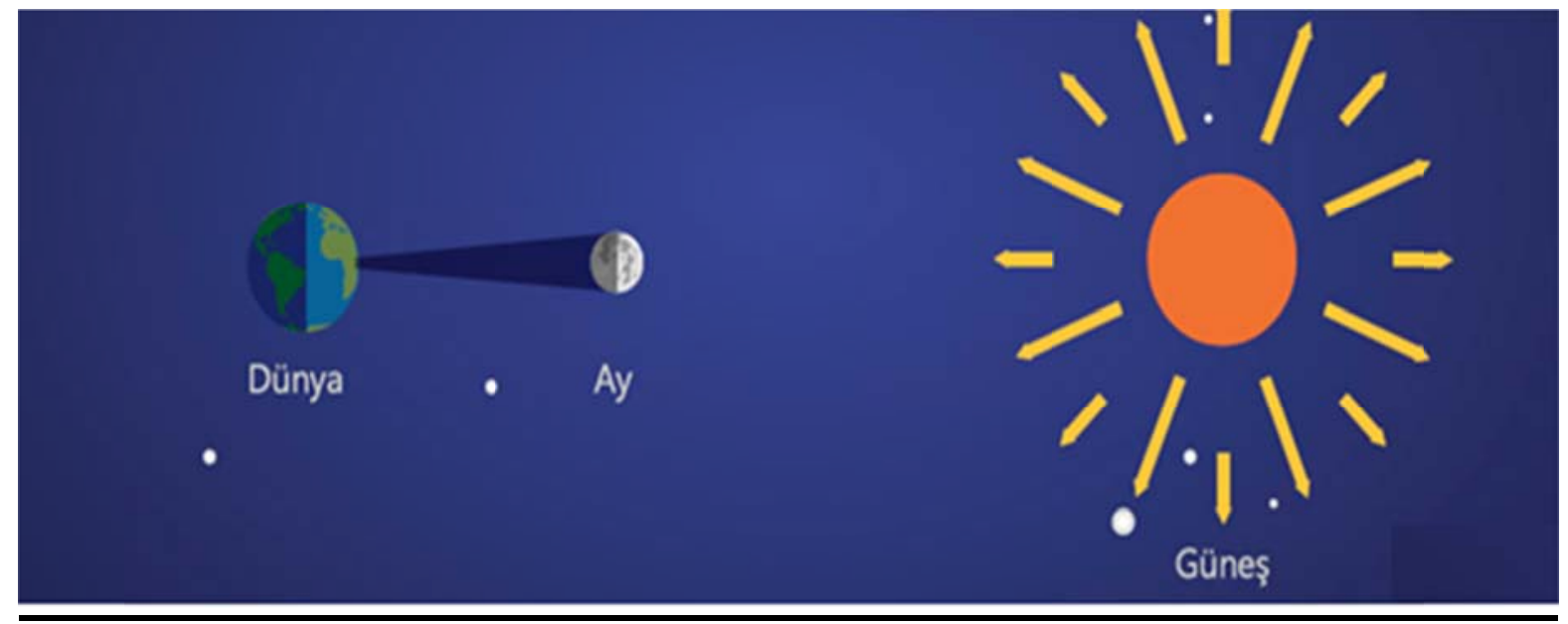

Image No 7: Gündüz, G. (2013). Ortaokul 5.sınıf fen bilimleri ders kitabı. Işı̆̆ın ve sesin yayılması (ss. 96-118). Ankara: Evren Yayınc1lık.

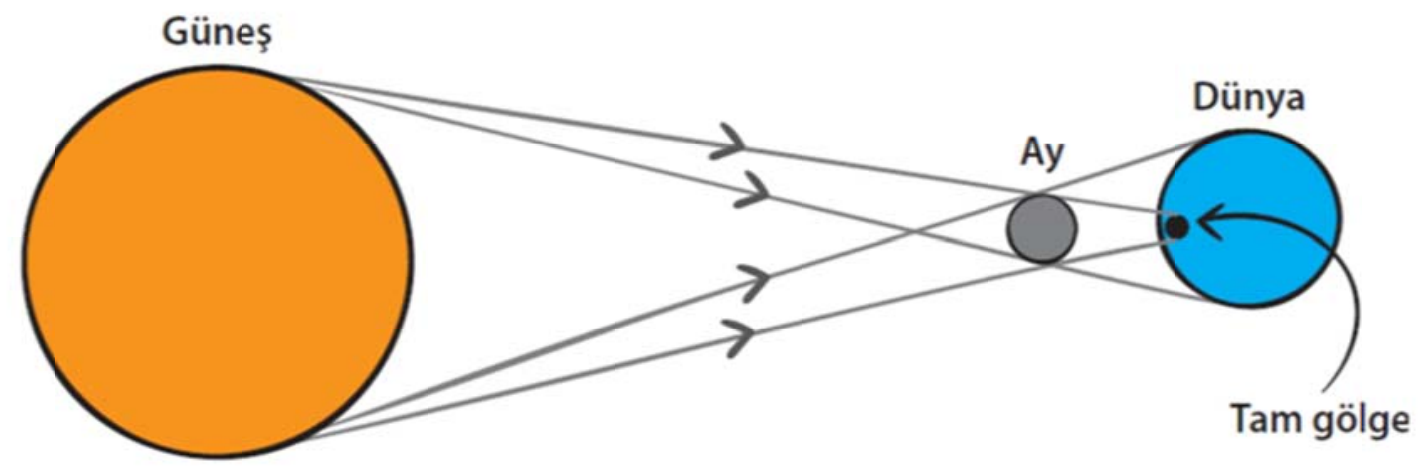

Image No 8: Komisyon (2014). Ortaokul 5.sınıf fen bilimleri ders kitabı. Işığıın ve sesin yayılması (ss. 161-216). Ankara: MEB Yayınları.

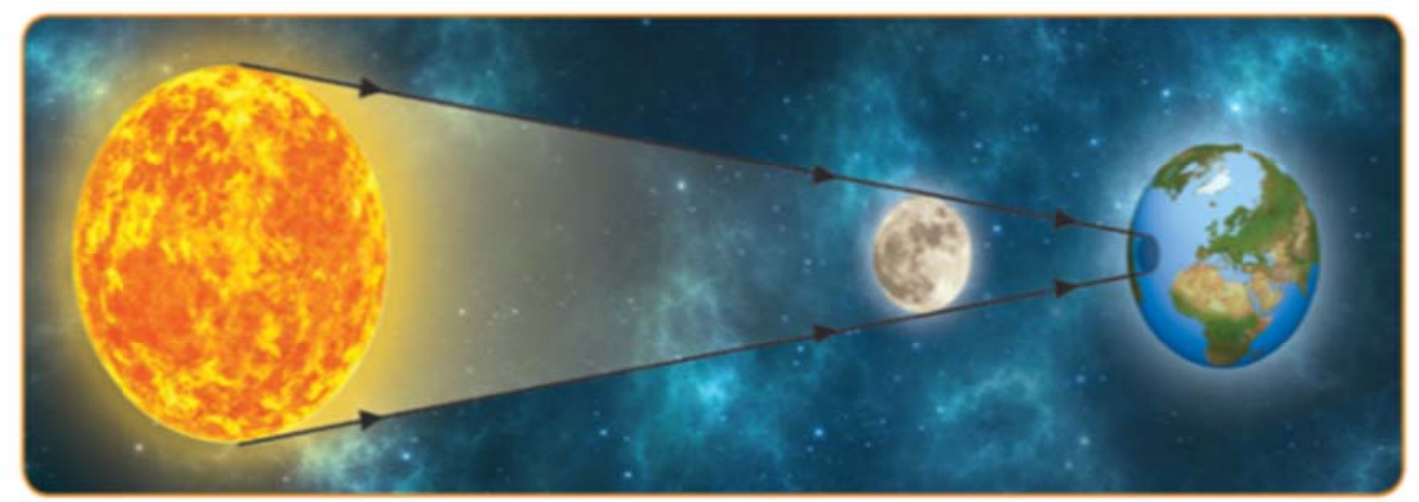

Image No 9: Bayram, G. \& Kibar, F. S. (2014). Ortaokul 5.sınıf fen bilimleri ders kitabı. Işı̆̆ın ve sesin yayılması (ss. 103-120). Ankara: Sevgi Yayınları 


\section{REFERENCES}

- Allan, G. (2003). A critique of using grounded theory as a research method. Electronic Journal of Business Research Methods, 2(1), 1-10.

- Bektaşl1, B. (2014). In-service science teachers' astronomy misconceptions. Mediterranean Journal of Educational Research, 15, 1-10.

- Brunsell, E. \& Marcks, J. (2005). Identifying a baseline for teachers' astronomy content knowledge. Astronomy Education Review, 3(2), 38-46.

- Deming, G. L. (2001). Results from the astronomy diagnostic test national project. Astronomy Education Review, 1(1), 52-57.

- Emrahoğlu, N. \& Öztürk, A. (2009). Fen bilgisi öğretmen adaylarının astronomi kavramlarını anlama seviyelerinin ve kavram yanılgılarının incelenmesi üzerine boylamsal bir araştırma. Çukurova Üniversitesi Sosyal Bilimler Enstitüsü Dergisi, 18(1), 165-180.

- Hudgins, D. W., Prather, E. E., Grayson, D. J. \& Smits, D. P. (2006). Effectiveness of collaborative ranking tasks on student understanding of key astronomy concepts. Astronomy Education Review, 5(1), 1-22.

- Kalkan, H. \& Kiroglu, K. (2007). Science and non-science students' ideas about basic astronomy concepts in pre-service training for elementary school teachers. Astronomy Education Review, 6(1), 15-24.

- Lee, V. R. (2010). Adaptations and continuities in the use and design of visual representations in US middle school science textbooks. International Journal of Science Education, 32(8), 1099-1126.

- Lelliott, A. \& Rollnick, M. (2010). Big ideas: A review of astronomy education research 1974-2008. International Journal of Science Education, 32(13), 1771-1799.

- MEB (Turkish Ministry of National Education) (2013). Science curriculum for grades $3,4,5,6,7$ and 8. Retrieved from http://ttkb.meb.gov.tr/www/guncellenen-ogretimprogramlari/icerik/151, 25 January 2015.

- Nyachwaya, J. M. \& Wood, N. B. (2014). Evaluation of chemical representations in physical chemistry textbooks. Chemistry Education Research and Practice, 15, 720728.

- Pena, B. M. \& Quilez, M. J. G. (2001). The importance of images in astronomy education. International Journal of Science Education, 23(11), 1125-1135.

- Şahin, Ç., Bülbül, E. \& Durukan, Ü. G. (2013). Öğrencilerin gök cisimleri konusundaki alternatif kavramlarının giderilmesinde kavramsal değişim metinlerinin etkisi. Journal of Computer and Education Research, 1(2), 38-64.

- Topsakal, U. U. \& Oversby, J. (2013). What do scientist and non-scientist teachers notice about biology diagrams? Journal of Biological Education, 47(1), 21-28. 